\title{
American College of Obstetricians and Gynecologists practice bulletins: An overview
}

\author{
Suneet P. Chauhan \\ Aurora Health Care \\ Vincenzo Berghella \\ Thomas Jefferson University \\ Maureen Sanderson \\ University of Texas \\ Everett F. Magann \\ Aurora Health Care \\ John C. Morrison

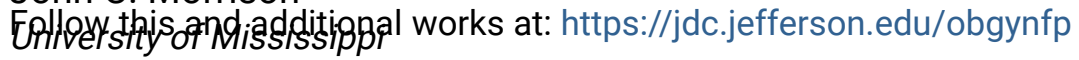 \\ Part of the Obstetrics and Gynecology Commons \\ Let us know how access to this document benefits you
}

\section{Recommended Citation}

Chauhan, Suneet P.; Berghella, Vincenzo; Sanderson, Maureen; Magann, Everett F.; and Morrison, John C., "American College of Obstetricians and Gynecologists practice bulletins: An overview" (2006). Department of Obstetrics and Gynecology Faculty Papers. Paper 2.

https://jdc.jefferson.edu/obgynfp/2

This Article is brought to you for free and open access by the Jefferson Digital Commons. The Jefferson Digital Commons is a service of Thomas Jefferson University's Center for Teaching and Learning (CTL). The Commons is a showcase for Jefferson books and journals, peer-reviewed scholarly publications, unique historical collections from the University archives, and teaching tools. The Jefferson Digital Commons allows researchers and interested readers anywhere in the world to learn about and keep up to date with Jefferson scholarship. This article has been accepted for inclusion in Department of Obstetrics and Gynecology Faculty Papers by an authorized administrator of the Jefferson Digital Commons. For more information, please contact: JeffersonDigitalCommons@jefferson.edu. 


\title{
American College of Obstetricians and Gynecologists practice bulletins: An overview
}

\author{
Suneet P. Chauhan, MD ${ }^{\text {a }}$ \\ Vincenzo Berghella, MD ${ }^{b}$ \\ Maureen Sanderson, PhD $^{\mathrm{c}}$ \\ Everett F. Magann, MD ${ }^{a}$ \\ John C. Morrison, MD ${ }^{\text {d }}$ \\ ${ }^{\text {a }}$ Division of Maternal-Fetal Medicines Aurora Health Care, West Allis, WI \\ b Department of Obstetrics \& Gynecology, Division of Maternal Fetal Medicine, Thomas Jefferson University, Philadelphia, PA \\ ${ }^{c}$ University of Texas School of Public Health at Brownsville, Brownsville, TX \\ d Department of Obstetrics \& Gynecology, Division of Maternal-Fetal Medicine, University of Mississippi, Jackson, MI
}

Presented at the 72nd Annual Meeting of the Central Association of Obstetricians and Gynecologists, October 19-22, 2005, Scottsdale, AZ.

\section{Objective}

The purpose of this study was to review the American College of Obstetricians and Gynecologists practices bulletins to quantify the type of recommendations and references and determining whether there are any differences between obstetric and gynecologic bulletins.

\section{Study design}

All practice bulletins published from June 1998 to December 2004 were reviewed. Odds ratios and 95\% confidence intervals were calculated.

\section{Results}

The 55 practice bulletins contained 438 recommendations of which $29 \%$ are level $A, 33 \%$ level $B$, and $38 \%$ level C. The 55 bulletins cite 3953 references of which $17 \%$ are level I, 46\% level II, 34\% level III, and 3\% others. Level A recommendations were significantly more likely among the 23 gynecologic than 32 obstetric bulletins (37\% versus $23 \%$, odds ratios 1.95 , 95\% confidence intervals $1.28,2.96)$. The study types referenced in obstetric and gynecologic bulletins were similar $(P>.05$ for comparison of levels I, II, and III and meta-analysis references).

\section{Conclusion}

Only 29\% of the American College of Obstetricians and Gynecologists recommendations are level A, based on good and consistent scientific evidence.

To improve the quality of health care and decreasing its cost and diminishing professional liability, the American College of Obstetricians and Gynecologists (ACOG) publishes evidence-based practice guidelines. ${ }^{1}$ ACOG practice bulletins are perhaps the most influential publications for clinicians involved with obstetric and gynecologic care. The topics for these bulletins are selected on the basis of unexplained variations in 
practice or difference between scientific knowledge and clinical practice. ${ }^{1}$ After extensive search of the documents published in English, the literature is analyzed according to the method used by the U.S. Preventive Services Task Force. Each report is classified as being level I, II-1, II-2, II-3, III, meta-, decision-, or cost-benefit analysis. The synthesis of the literature leads to recommendations, categorized as A, B, C, D, or E, which are based on the highest level of evidence (Table I). ${ }^{1}$

Table I. Classification of references and recommendations, according to the U.S. Preventive Services Task Force*

\begin{tabular}{|c|c|}
\hline \multicolumn{2}{|l|}{ References } \\
\hline Level I & $\begin{array}{l}\text { Evidence obtained from at least } 1 \text { properly conducte } \\
\text { trial }\end{array}$ \\
\hline Level II-1 & $\begin{array}{l}\text { Evidence obtained from well-designed controlled stu } \\
\text { randomization }\end{array}$ \\
\hline Level II-2 & $\begin{array}{l}\text { Evidence from well-designed cohort or case-control } \\
\text { more than } 1 \text { center or research group }\end{array}$ \\
\hline Level II-3 & Evidence obtained from multiple time series with or \\
\hline Level III & $\begin{array}{l}\text { Opinions of respected authorities, based on clinica } \\
\text { studies, or reports of expert committees }\end{array}$ \\
\hline Meta-analysis & A systematic structured process that is more than a 1 \\
\hline Decision analysis & $\begin{array}{l}\text { Use of mathematical models of sequences of sever } \\
\text { which is optimal }\end{array}$ \\
\hline Cost-efficient analysis & $\begin{array}{l}\text { Comparison of health care practice or techniques in } \\
\text { economic efficiencies in providing health benefits }\end{array}$ \\
\hline \multicolumn{2}{|l|}{ Recommendations } \\
\hline Level A & Based on good and consistent scientific evidence \\
\hline Level B & Based on limited or inconsistent scientific evidence \\
\hline Level C & Based primarily on consensus and expert opinion \\
\hline Level D & Fair evidence against the recommendation \\
\hline Level E & Evidence against the recommendation \\
\hline
\end{tabular}

*Adapted from American College of Obstetricians and Gynecologists. Reading the medical literature: applying evidence to practice. Washington DC: American College of Obstetricians and Gynecologists; 1998.

While reading these publications individually, it occurred to us that clinicians would benefit from an overview of all practice bulletins. A summary of the number of these bulletins, recommendations, and their subtypes and the type of studies used to derive them would allow a greater appreciation for ACOG publications. Furthermore, the summation would allow researchers to focus on the areas in which there are insufficient type I studies or lack of level A recommendations.

The purpose of this descriptive study was to review the practice bulletins published by ACOG and quantify the following: (1) number and grades of recommendations, (2) types of the reports cited in the references section, and (3) source of the references. Gilbert and Pitkin ${ }^{2}$ recently classified the site of publications for obstetric-gynecology manuscripts 
into weekly journals (Journal of the American Medical Association, New England Journal of Medicine, and Lancet), monthly obstetric-gynecologic journals (American Journal of Obstetrics and Gynecology and Obstetrics and Gynecology), and others. Moreover, we wanted to see whether there were any differences between the obstetric and gynecologic practice bulletins with regard to these 3 variables.

\section{Material and methods}

From the list of titles published in December $2004,{ }^{3}$ we identified all current ACOG practice bulletins. Each publication was reviewed by 1 author (S.P.C.), and the following information was entered in Excel spreadsheet (Microsoft, Seattle, WA): number, time of publication, title, clinicians who assisted with the development of the bulletins, total number as well as the type of recommendations, the total number of references, and the quality of the study, as determined by the criteria published by U.S. Preventive Services Task Force. We excluded practice bulletins that have been withdrawn along with education bulletins, practice patterns, and committee opinions.

Student $t$ test or $\chi^{2}$ tests were used where applicable. For proportion data, odds ratios (ORs) and 95\% confidence intervals (CIs) were calculated. Pearson correlation coefficients were calculated to determine whether there was a relationship between the grade of recommendation and the types of studies referenced or the journals in which they were published. The SAS package (SAS Institute, Cary, NC) was used and $P<.05$ was considered significant.

\section{Results}

During 78 months (June 1998, when the first one was published, to December 2004), 58 practice bulletins were published by ACOG, at the rate of 1 every 1.3 months. Three of these (numbers 2, 5, 32) have been withdrawn, leaving 55 for review. 4, 5, 6, 7, 8, 9, 10, 11, 12, 13, 14, 15, $16,17,18,19,20,21,22,23,24,25,26,27,28,29,30,31,32,33,34,35,36,37,38,39,40,41,42,43,44,45,46,47,48,49,50,51,52,53,54,55,56,57,58$

All but $1^{14}$ was credited as being developed with the assistance of at least 1 clinician. Overall there were 76 physicians, or a median of 1.0 with $95 \%$ CI of 1.2 and 1.6 per bulletin, that were mentioned as developing these publications. The maximum number of assistants for 1 bulletin was 5, and this one was a collaborative effort between ACOG and the Society of Maternal-Fetal Medicine. ${ }^{56}$

Among these 55 bulletins, 4, 5, 6, 7, 8, 9, 10,11, 12, 13, 14, 15, 16, 17, 18, 19, 20, 21, 22, 23, 24, 25, 26, 27, 28, 29, 30, 31, 32, 33, 34, 35, 36, $37,38,39,40,41,42,43,44,45,46,47,48,49,50,51,52,53,54,55,56,57,58$ there were 438 recommendations. Twentynine percent $(\mathrm{n}=128)$ were level A, 33\% $(n=143)$ were level $\mathrm{B}$, and $38 \%(n=167)$ were level $\mathrm{C}$. There were no level D or E recommendations. Twenty-seven percent $(15 / 55)$ of the bulletins had no level A recommendations, ${ }^{5,8,9,10,20,21,29,31,34,40,42,47,48,56,58}$ and $7 \%(4 / 55)$ had only level C., 20,29,47 The median number of recommendations per bulletin was $8.0 \pm 3.1$, with $2.3 \pm 2.1$ being level A, $2.6 \pm 2.1$ being level B, and $3.0 \pm 1.9$ being level C. 


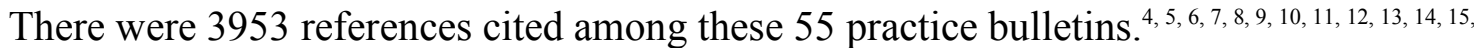
$16,17,18,19,20,21,22,23,24,25,26,27,28,29,30,31,32,33,34,35,36,37,38,39,40,41,42,43,44,45,46,47,48,49,50,51,52,53,54,55,56,57,58$

Seventeen percent $(n=686)$ were level I-1; 3\% $(n=108)$ were level II-1; 25\% $(n=974)$ were level II-2; 19\% $(n=738)$ were II-3; 34\% $(n=1327)$ were level III ; 3\% $(n=104)$ were meta-analyses; $0.3 \%(n=11)$ were cost-effective analyses; and $0.1 \%(n=5)$ were decision analyses.

Whereas 5\% (187) of the cited references were published in the New England Journal of Medicine, 3\% (111) appeared in the Journal of the American Medical Association and $2 \%$ (96) in Lancet. Thus, 10\% (394/3953) appeared in the 3 weekly general journals.

Overall, $30 \%$ (1198) of the references were published in the 2 major obstetricgynecologic journals (17\% [669] in the American Journal of Obstetrics and Gynecology and 13\% [529] in Obstetrics and Gynecology). The remaining 2361 references $(60 \%)$ were published in other sources. Interestingly, $1 \%(38)$ of the references were from the Cochrane database and 0.5\% (18) were ACOG publications.

Of the 55 practice bulletins, $4,5,6,7,8,9,10,11,12,13,14,15,16,17,18,19,20,21,22,23,24,25,26,27,28,29,30,31,32,33,34,35$,

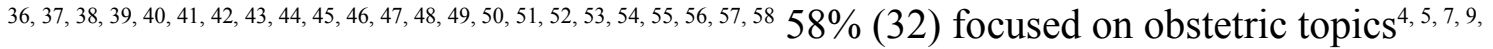
$10,11,13,14,18,20,21,22,23,25,28,30,31,32,33,36,37,38,40,43,44,47,48,49,52,54,55,56,58$ and $42 \%$ (23) on gynecologic (Tables II and III). 5, 8, 12, 15, 16, 17, 19, 22, 24, 26, 27, 29, 34, 35, 39, 41, 42, 45, 46, 50, 51, 53, 57 Comparison of the bulletins in the 2 areas indicates that gynecologic bulletins had significantly different distribution for the 3 levels of recommendations (Figure; $p=0.007$ ). Bulletins focused on gynecologic issues had significantly more level A recommendations $(37 \%$; 74/202) than those dealing with obstetrics $(23 \%$; 54/236; OR 1.95, 95\% CI 1.26, 3.02).

Table II. The obstetric practice bulletins

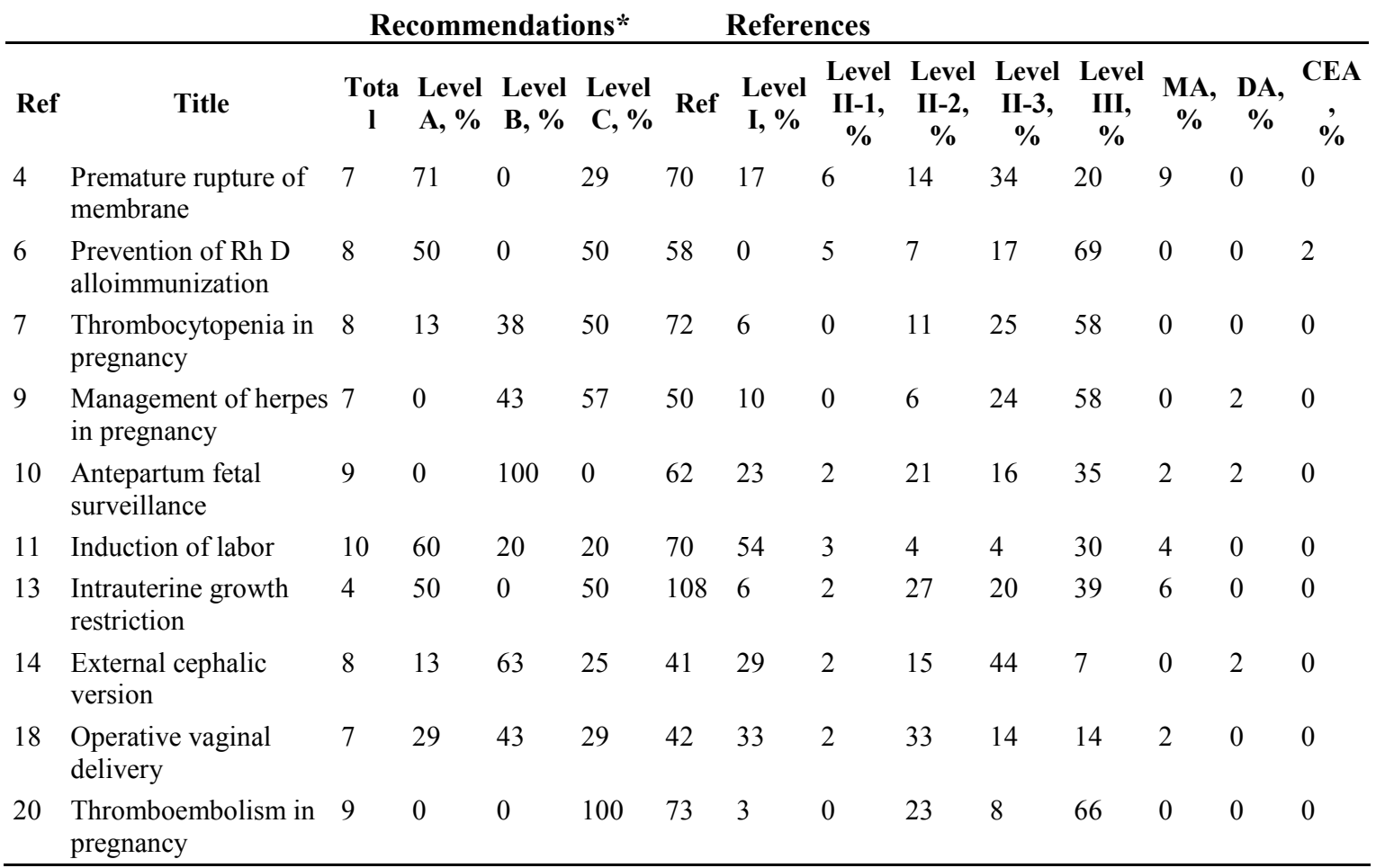




\begin{tabular}{|c|c|c|c|c|c|c|c|c|c|c|c|c|c|c|}
\hline Ref & Title & $\begin{array}{c}\text { Tota } \\
1\end{array}$ & $\begin{array}{l}\text { Level } \\
\text { A, \% }\end{array}$ & $\begin{array}{l}\text { Level } \\
\text { B, \% }\end{array}$ & $\begin{array}{r}\text { Level } \\
\text { C, } \%\end{array}$ & Ref & $\begin{array}{l}\text { Level } \\
\text { I, \% }\end{array}$ & $\begin{array}{c}\text { Level } \\
\text { II-1, } \\
\%\end{array}$ & $\begin{array}{c}\text { Level } \\
\text { II-2, } \\
\%\end{array}$ & $\begin{array}{c}\text { Level } \\
\text { II-3, } \\
\%\end{array}$ & $\begin{array}{c}\text { Level } \\
\text { III, } \\
\%\end{array}$ & $\begin{array}{c}\text { MA, } \\
\%\end{array}$ & $\begin{array}{c}\text { DA, } \\
\%\end{array}$ & $\begin{array}{c}\text { CEA } \\
\%\end{array}$ \\
\hline 21 & $\begin{array}{l}\text { Perinatal viral and } \\
\text { parasitic infections }\end{array}$ & 10 & 0 & 50 & 50 & 131 & 3 & 2 & 11 & 31 & 52 & 0 & 0 & 1 \\
\hline 23 & Fetal macrosomia & 5 & 20 & 60 & 20 & 94 & 1 & 1 & 53 & 28 & 14 & 3 & 0 & 0 \\
\hline 25 & $\begin{array}{l}\text { Management of } \\
\text { recurrent early } \\
\text { pregnancy loss }\end{array}$ & 8 & 25 & 25 & 50 & 105 & 15 & 1 & 38 & 23 & 17 & 6 & 0 & 0 \\
\hline 28 & $\begin{array}{l}\text { Prenatal diagnosis of } \\
\text { fetal chromosomal } \\
\text { abnormalities }\end{array}$ & 9 & 11 & 0 & 89 & 76 & 9 & 1 & 28 & 32 & 29 & 1 & 0 & 0 \\
\hline 30 & $\begin{array}{l}\text { Chronic hypertension } \\
\text { in pregnancy }\end{array}$ & 8 & 13 & 50 & 38 & 52 & 6 & 2 & 10 & 25 & 48 & 10 & 0 & 0 \\
\hline 31 & Gestational diabetes & 9 & 0 & 67 & 33 & 105 & 12 & 6 & 50 & 16 & 16 & 0 & 0 & 0 \\
\hline 32 & $\begin{array}{l}\text { Assessment of risk } \\
\text { factors for preterm } \\
\text { birth }\end{array}$ & 4 & 25 & 75 & 0 & 80 & 20 & 3 & 33 & 10 & 30 & 5 & 0 & 0 \\
\hline 33 & $\begin{array}{l}\text { Diagnosis and } \\
\text { management of } \\
\text { preeclampsia and } \\
\text { eclampsia }\end{array}$ & 10 & 40 & 30 & 30 & 63 & 16 & 0 & 24 & 19 & 41 & 0 & 0 & 0 \\
\hline 36 & $\begin{array}{l}\text { Obstetrics analgesia } \\
\text { and anesthesia }\end{array}$ & 11 & 18 & 27 & 55 & 116 & 33 & 10 & 22 & 19 & 15 & 2 & 0 & 0 \\
\hline 37 & $\begin{array}{l}\text { Thyroid disease in } \\
\text { pregnancy }\end{array}$ & 8 & 13 & 25 & 63 & 51 & 0 & 6 & 35 & 16 & 43 & 0 & 0 & 0 \\
\hline 38 & $\begin{array}{l}\text { Perinatal care at the } \\
\text { threshold of viability }\end{array}$ & 7 & 29 & 43 & 29 & 32 & 3 & 0 & 44 & 25 & 28 & 0 & 0 & 0 \\
\hline 40 & Shoulder dystocia & 5 & 0 & 40 & 60 & 51 & 4 & 0 & 37 & 29 & 29 & 0 & 0 & 0 \\
\hline 43 & $\begin{array}{l}\text { Management of } \\
\text { preterm labor }\end{array}$ & 7 & 57 & 43 & 0 & 74 & 55 & 1 & 11 & 5 & 26 & 1 & 0 & 0 \\
\hline 44 & Neural tube defects & 8 & 50 & 25 & 25 & 81 & 6 & 0 & 26 & 15 & 52 & 1 & 0 & 0 \\
\hline 47 & $\begin{array}{l}\text { Prophylactic } \\
\text { antibiotics in labor and } \\
\text { delivery }\end{array}$ & 4 & 0 & 0 & 100 & 59 & 36 & 2 & 12 & 10 & 36 & 5 & 0 & 0 \\
\hline 48 & Cervical insufficiency & 6 & 0 & 67 & 33 & 56 & 13 & 0 & 43 & 16 & 27 & 2 & 0 & 0 \\
\hline 49 & $\begin{array}{l}\text { Dystocia and } \\
\text { augmentation of labor }\end{array}$ & 7 & 29 & 43 & 29 & 61 & 41 & 2 & 23 & 15 & 8 & 10 & 2 & 0 \\
\hline 52 & $\begin{array}{l}\text { Nausea and vomiting } \\
\text { of pregnancy }\end{array}$ & 9 & 33 & 44 & 22 & 94 & 11 & 2 & 34 & 9 & 40 & 4 & 0 & 0 \\
\hline 54 & $\begin{array}{l}\text { Vaginal birth after } \\
\text { cesarean delivery }\end{array}$ & 7 & 29 & 29 & 43 & 105 & 1 & 0 & 48 & 16 & 28 & 4 & 1 & 3 \\
\hline 55 & $\begin{array}{l}\text { Management of } \\
\text { postterm pregnancy }\end{array}$ & 6 & 50 & 0 & 50 & 69 & 30 & 6 & 36 & 9 & 14 & 4 & 0 & 0 \\
\hline 56 & $\begin{array}{l}\text { Multiple gestation: } \\
\text { complicated twin, } \\
\text { triplet, and high-order } \\
\text { multifetal pregnancy }\end{array}$ & 8 & 0 & 38 & 63 & 141 & 9 & 6 & 34 & 17 & 34 & 0 & 0 & 0 \\
\hline 58 & $\begin{array}{l}\text { Ultrasonography in } \\
\text { pregnancy }\end{array}$ & 3 & 0 & 33 & 67 & 34 & 12 & 0 & 26 & 29 & 26 & 6 & 0 & 0 \\
\hline
\end{tabular}

Author's version of an article published in the American Journal of Obstetrics and Gynecology (2006) 194(6):1564-1572. Copyright (C) 2006 Mosby, Inc. 
Table III The gynecologic practice bulletins

\section{Recommendations* References}

\begin{tabular}{|c|c|c|c|c|c|c|c|c|c|c|c|c|c|c|}
\hline Ref & Title & Total & $\begin{array}{l}\text { Level } \\
\text { A, \% }\end{array}$ & $\begin{array}{l}\text { Level } \\
\text { B, \% }\end{array}$ & $\begin{array}{l}\text { Level } \\
\text { C, \% }\end{array}$ & Total & $\begin{array}{l}\text { Level } \\
\text { I, \% }\end{array}$ & $\begin{array}{c}\text { Level } \\
\text { II-1, } \\
\% \%\end{array}$ & $\begin{array}{c}\text { Level } \\
\text { II-2, } \\
\%\end{array}$ & $\begin{array}{c}\text { Level } \\
\text { II-3, } \\
\%\end{array}$ & $\begin{array}{l}\text { Level } \\
\text { III, \% }\end{array}$ & $\begin{array}{c}\text { MA, } \\
\%\end{array}$ & $\begin{array}{c}\text { DA, } \\
\%\end{array}$ & CEA, \% \\
\hline 5 & $\begin{array}{l}\text { Medical } \\
\text { management of tubal } \\
\text { pregnancy }\end{array}$ & 4 & 0 & 75 & 25 & 31 & 6 & 0 & 10 & 52 & 29 & 0 & 0 & 3 \\
\hline 8 & $\begin{array}{l}\text { Prophylactic } \\
\text { oophorectomy }\end{array}$ & 6 & 0 & 0 & 100 & 33 & 3 & 6 & 27 & 30 & 33 & 0 & 0 & 0 \\
\hline 12 & $\begin{array}{l}\text { Medical } \\
\text { management of } \\
\text { endometriosis }\end{array}$ & 7 & 29 & 43 & 29 & 99 & 23 & 6 & 13 & 4 & 52 & 2 & 0 & 0 \\
\hline 15 & $\begin{array}{l}\text { Management of } \\
\text { anovulatory bleeding }\end{array}$ & 4 & 50 & 0 & 50 & 38 & 29 & 0 & 21 & 13 & 34 & 3 & 0 & 0 \\
\hline 16 & $\begin{array}{l}\text { Premenstrual } \\
\text { syndrome }\end{array}$ & 12 & 33 & 42 & 25 & 60 & 35 & 8 & 12 & 10 & 35 & 0 & 0 & 0 \\
\hline 17 & $\begin{array}{l}\text { Surgical alternatives } \\
\text { to hysterectomy in } \\
\text { the management of } \\
\text { leiomyomas }\end{array}$ & 10 & 40 & 10 & 50 & 64 & 14 & 2 & 17 & 27 & 41 & 0 & 0 & 0 \\
\hline 19 & $\begin{array}{l}\text { The use of hormonal } \\
\text { contraception in } \\
\text { women with } \\
\text { coexisting medical } \\
\text { conditions }\end{array}$ & 15 & 40 & 40 & 20 & 92 & 7 & 2 & 38 & 22 & 32 & 0 & 0 & 0 \\
\hline 22 & $\begin{array}{l}\text { Prevention of deep } \\
\text { vein thrombosis and } \\
\text { pulmonary embolism }\end{array}$ & 4 & 50 & 0 & 50 & 65 & 12 & 0 & 25 & 2 & 55 & 6 & 0 & 0 \\
\hline 24 & $\begin{array}{l}\text { Antibiotic } \\
\text { prophylaxis for } \\
\text { gynecologic } \\
\text { procedures }\end{array}$ & 12 & 33 & 25 & 42 & 38 & 24 & 3 & 11 & 8 & 42 & 11 & 0 & 3 \\
\hline 26 & $\begin{array}{l}\text { Emergency oral } \\
\text { contraception }\end{array}$ & 10 & 40 & 20 & 40 & 38 & 18 & 0 & 3 & 45 & 29 & 5 & 0 & 0 \\
\hline 27 & $\begin{array}{l}\text { Medical } \\
\text { management of } \\
\text { abortion }\end{array}$ & 6 & 33 & 33 & 33 & 89 & 13 & 17 & 9 & 43 & 16 & 2 & 0 & 0 \\
\hline 29 & $\begin{array}{l}\text { Use of botanicals for } \\
\text { management of } \\
\text { menopausal } \\
\text { symptoms }\end{array}$ & 4 & 0 & 0 & 100 & 48 & 23 & 4 & 0 & 15 & 54 & 4 & 0 & 0 \\
\hline 34 & $\begin{array}{l}\text { Management of } \\
\text { infertility caused by } \\
\text { ovulatory } \\
\text { dysfunction }\end{array}$ & 5 & 0 & 100 & 0 & 58 & 9 & 2 & 24 & 17 & 48 & 0 & 0 & 0 \\
\hline 35 & $\begin{array}{l}\text { Diagnosis and } \\
\text { treatment of cervical } \\
\text { carcinoma }\end{array}$ & 8 & 25 & $50 \%$ & 25 & 58 & 12 & 0 & 17 & 24 & 45 & 2 & 0 & 0 \\
\hline 39 & $\begin{array}{l}\text { Selective estrogen } \\
\text { receptor modulators }\end{array}$ & 9 & 56 & 0 & 44 & 67 & 70 & 0 & 6 & 1 & 19 & 3 & 0 & 0 \\
\hline 41 & $\begin{array}{l}\text { Polycystic ovary } \\
\text { syndrome }\end{array}$ & 14 & 29 & 21 & 50 & 101 & 18 & 2 & 42 & 13 & 24 & 2 & 0 & 0 \\
\hline 42 & Breast cancer & 4 & 0 & 50 & 50 & 94 & 19 & 1 & 16 & 16 & 39 & 9 & 0 & 0 \\
\hline
\end{tabular}

Author's version of an article published in the American Journal of Obstetrics and Gynecology (2006) 194(6):1564-1572. Copyright (C) 2006 Mosby, Inc. 


\begin{tabular}{|c|c|c|c|c|c|c|c|c|c|c|c|c|c|c|}
\hline Ref & Title & Total & $\begin{array}{c}\text { Level } \\
\text { A, \% }\end{array}$ & $\begin{array}{l}\text { Level } \\
\text { B, \% }\end{array}$ & $\begin{array}{l}\text { Level } \\
\text { C, \% }\end{array}$ & Total & $\begin{array}{c}\text { Level } \\
\text { I, \% }\end{array}$ & $\begin{array}{c}\text { Level } \\
\text { II-1, } \\
\%\end{array}$ & $\begin{array}{c}\text { Level } \\
\text { II-2, } \\
\%\end{array}$ & $\begin{array}{c}\text { Level } \\
\text { II-3, } \\
\%\end{array}$ & $\begin{array}{l}\text { Level } \\
\text { III, \% }\end{array}$ & $\begin{array}{c}\text { MA, } \\
\%\end{array}$ & $\begin{array}{c}\text { DA, } \\
\%\end{array}$ & CEA, \% \\
\hline & screening & & & & & & & & & & & & & \\
\hline 45 & $\begin{array}{l}\text { Cervical cytology } \\
\text { screening }\end{array}$ & 12 & 42 & 25 & 33 & 79 & 5 & 1 & 37 & 15 & 33 & 5 & 0 & 4 \\
\hline 46 & $\begin{array}{l}\text { Benefits and risks of } \\
\text { sterilization }\end{array}$ & 7 & 71 & 0 & 29 & 104 & 11 & 2 & 42 & 15 & 30 & 0 & 0 & 0 \\
\hline 50 & Osteoporosis & 10 & 40 & 50 & 10 & 78 & 46 & 8 & 17 & 10 & 17 & 1 & 0 & 1 \\
\hline 51 & Chronic pelvic pain & 19 & 37 & 47 & 16 & 150 & 29 & 1 & 15 & 20 & 31 & 4 & 0 & 0 \\
\hline 53 & $\begin{array}{l}\text { Diagnosis and } \\
\text { treatment of } \\
\text { gestational } \\
\text { trophoblastic disease }\end{array}$ & 13 & 54 & 15 & 31 & 49 & 8 & 0 & 24 & 12 & 55 & 0 & 0 & 0 \\
\hline 57 & $\begin{array}{l}\text { Gynecologic herpes } \\
\text { simplex virus } \\
\text { infection }\end{array}$ & 7 & 71 & 29 & 0 & 44 & 14 & 0 & 18 & 39 & 30 & 0 & 0 & 0 \\
\hline
\end{tabular}

*The percent for 3 recommendations add up to $100 \%$ and are based on total of 207 recommendations; the percent for the 8 types of references add up to $100 \%$ and are based on 1557 citations in the gynecologic bulletins. Ref, Reference; $M A$, meta-analysis; $D A$, decision analysis; $C E A$, cost-effectiveness analysis.

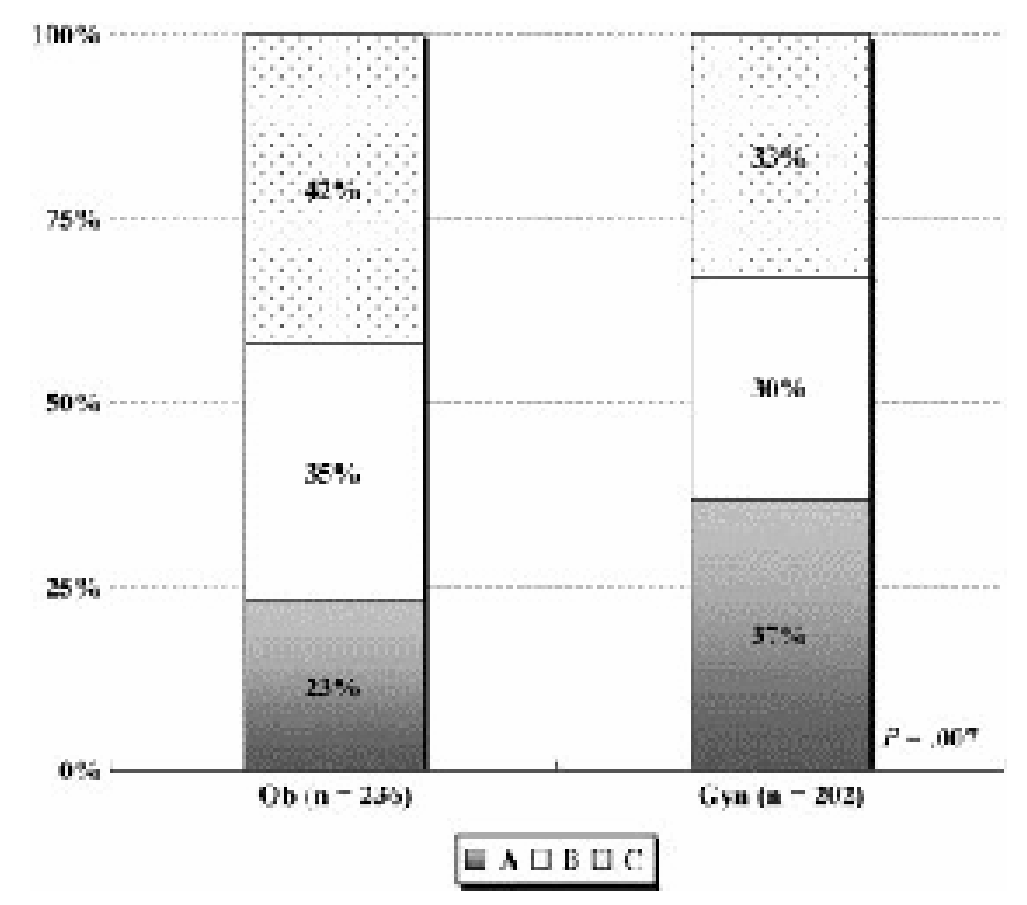

Figure Recommendations in obstetric and gynecologic ACOG practice bulletins,

Preventive classified according to the criteria promulgated by the U.S.

Services Task Force. Level A, based on good and consistent scientific evidence; level B, based on limited or inconsistent scientific evidence, and level $\mathrm{C}$, based primarily on consensus and expert opinion.

Author's version of an article published in the American Journal of Obstetrics and Gynecology (2006) 194(6):1564-1572. Copyright (C) 2006 Mosby, Inc. 
The mean number of level A recommendations were significantly higher in gynecologic bulletins than obstetric; otherwise the 2 groups were similar with regard to level $\mathrm{B}$ or $\mathrm{C}$ conclusions as well as the types of studies referenced (Table IV). Similar fractions of obstetric $(31 \% \text { or } 10 / 32)^{9,10,20,21,31,40,47,48,56,58}$ and gynecologic bulletins $(22 \% \text { or } 5 / 23)^{5,8,29 \text {, }}$ 34,42 had no level A recommendations (OR 1.64, 95\% CI 0.41, 7.21). Moreover, the number of bulletins with only level $\mathrm{C}$ recommendations was similar for the 2 groups $(6 \%$ [2/32] for obstetrics ${ }^{20,47}$ and $9 \%$ [2/23] for gynecologic bulletins ${ }^{8,29}$ : OR 0.70, 95\% CI $0.05,10.44)$.

Table IV. Comparison of obstetric and gynecologic practice bulletins.

\begin{tabular}{lllc}
\hline & \multicolumn{1}{c}{ Obstetric $(\boldsymbol{n}=\mathbf{3 2})$} & \multicolumn{1}{c}{ Gynecologic $(\boldsymbol{n}=\mathbf{2 3})$} & $\boldsymbol{P}$ \\
Recommendations/bulletin & $8(2.5)$ & $8(7)$ & .148 \\
Level A & $1(2.5)$ & $4(3)$ & .054 \\
Level B & $3(1.5)$ & $2(4)$ & .950 \\
Level C & $3(2)$ & $3(2)$ & .899 \\
References/bulletin & $70(40)$ & $64(48)$ & .292 \\
Level I & $8.5(11.5)$ & $9(12)$ & .168 \\
Level II-1 & $1(2)$ & $1(2)$ & .519 \\
Level II-2 & $16(17)$ & $11(9)$ & .704 \\
Level II-3 & $12(12)$ & $12(11)$ & .316 \\
Level III & $21.5(19)$ & $26(16)$ & .227 \\
Meta-analysis & $1(3.5)$ & $1(2)$ & .198 \\
Published in & $10 \%(229)$ & $10 \%(165)$ & $<.001$ \\
Weekly general journals* & $39 \%(933)$ & $17 \%(265)$ & \\
AJOG and Obstet Gynecol & $51 \%(1214)$ & $73 \%(1147)$ & \\
Other sources & & & \\
Data presented as median and interquartile range or percent $(n)$. & $A J O G$, American Journal of Obstetrics and \\
Gynecology. & &
\end{tabular}

The tier of journal publications differed significantly between obstetric and gynecologic bulletins, with a greater proportion of articles published in weekly general journals for obstetric bulletins (Table II).

Several Spearman correlation coefficients were calculated to see whether the type of studies referenced in the bulletin or the journal in which the article was published was correlated with the type of recommendation (Table V). In all the practice bulletins and for obstetric subsets, there was a significant correlation between level A recommendations and level I references $(P<.05)$. Obstetric level $\mathrm{C}$ recommendations and level III references were also significantly correlated $(P=.02)$. Three significant correlations were noted for the references published: (1) level A recommendations in gynecologic bulletins and publications in the American Journal of Obstetrics and Gynecology and Obstetrics 
and Gynecology $(P=.008)$; (2) level B recommendations in gynecologic bulletins and other journals $(P=.02)$; and (3) level $\mathrm{C}$ recommendations in obstetric bulletins and other journals $(P=.03)$.

Table V . Correlation between levels of recommendations, levels of references, and journal published in which the references were published.

\begin{tabular}{|c|c|c|c|c|c|c|c|c|c|}
\hline & \multicolumn{3}{|c|}{ All practice bulletins } & \multicolumn{3}{|c|}{$\begin{array}{l}\text { Obstetric practice } \\
\text { bulletins }\end{array}$} & \multicolumn{3}{|c|}{$\begin{array}{l}\text { Gynecologic practice } \\
\text { bulletins }\end{array}$} \\
\hline & $\mathbf{A}$ & B & $\mathbf{C}$ & $\mathbf{A}$ & B & $\mathbf{C}$ & $\mathbf{A}$ & B & $\mathbf{C}$ \\
\hline \multicolumn{10}{|l|}{ References } \\
\hline Level I & $0.27^{*}$ & 0.13 & -0.16 & 0.23 & 0.12 & -0.24 & 0.14 & 0.07 & -0.008 \\
\hline Level II-1 & 0.07 & 0.12 & 0.10 & 0.20 & -0.004 & 0.12 & -0.10 & 0.25 & 0.08 \\
\hline Level II-2 & -0.01 & 0.15 & 0.03 & -0.08 & 0.04 & 0.05 & 0.32 & 0.27 & -0.07 \\
\hline Level II-3 & -0.09 & 0.18 & 0.12 & -0.19 & 0.12 & 0.28 & 0.18 & 0.27 & -0.12 \\
\hline Level III & 0.02 & 0.05 & 0.24 & -0.08 & -0.07 & $0.42^{*}$ & 0.15 & 0.20 & -0.09 \\
\hline Meta-analysis & 0.16 & -0.14 & -0.15 & 0.37 & -0.23 & -0.38 & -0.04 & -0.01 & 0.19 \\
\hline \multicolumn{10}{|l|}{ Published in } \\
\hline Weekly general journals & -0.06 & -0.10 & 0.11 & -0.15 & -0.13 & 0.26 & 0.09 & -0.12 & -0.10 \\
\hline AJOG and Obstet Gynecol & -0.02 & 0.07 & -0.05 & 0.08 & 0.09 & -0.26 & $0.47^{\S}$ & 0.01 & 0.13 \\
\hline Others & 0.21 & 0.18 & 0.18 & 0.06 & 0.01 & 0.45 & 0.24 & $0.43 *$ & -0.13 \\
\hline \multicolumn{10}{|c|}{$\begin{array}{l}\text { Data presented as Spearman correlation }(\mathrm{R}) ; P<.05 \text {, for the correlation, are in bold; otherwise the } P>.05 . \text { AJOG, } \\
\text { American Journal of Obstetrics and Gynecology; Obstet Gynecol, Obstetrics Gynecology. }\end{array}$} \\
\hline \multicolumn{10}{|l|}{$* P=.04$} \\
\hline \multicolumn{10}{|l|}{$\begin{array}{l}\$ P=.02 . \\
\$ \text { New Engl } \\
\S P=.03 . \\
\| P=.01 .\end{array}$} \\
\hline
\end{tabular}

\section{Comment}

Few publications are as influential for clinicians involved with obstetrics and gynecology in the United States as the ACOG practice bulletins. They search the relevant studies on the topics, synthesize the literature, and condense it to practical recommendations. Additionally, using the guidelines promulgated by the U.S. Preventive Services Task Force, these documents objectively classify not only the publications that lead to guidelines but also the recommendations themselves (Table I). Since its first publication in June $1998,{ }^{4}$ the practice bulletins have become fundamental reading for clinicians. An overview of all bulletins over the last 6.5 years not only provides interesting insights but also documents the areas with deficient clinical research that should lead to funded or multicenter research to fill the gaps in our knowledge.

There are 4 findings of this summary article. First, it provides an overview of how many recommendations (438) are contained in the 55 bulletins and their categories $(29 \%$ level A, 33\% level B, and 38\% level C) as well as the type of studies that led to them. Specifically, the 438 guidelines are based on 3953 references, 17\% of which are level I, 
$46 \%$ level II (includes II-1, II-2, II-3), 34\% are level III, and the remaining 3\% are meta-, decision, or cost-efficient analyses. Within level II studies, II-1 was the least common ( $3 \%$ or $108 / 3953)$ and II- 2 the most common ( $25 \%$ or $974 / 3953)$.

The finding of lack of randomized clinical trials and systemic review articles is consistent with an editorial by Scott, ${ }^{59}$ who noted that $70 \%$ of what obstetricians and gynecologists do are without these types of studies. Although randomized trials are the ideal way to avoid biases inherent in observational reports ${ }^{60}$ it should not be assumed that clinical outcome can not be improved without them ${ }^{61}$ that all randomizations adhere to concealment of the allocation process ${ }^{62}$ and that all observational reports are misleading. ${ }^{63}$ Lastly, as pointed out by Parer,${ }^{64}$ in obstetrics the availability of randomized clinical trials do not always translate into clinical acceptance and compliance. Despite these arguments, the review shows the need for additional well-conducted, randomized clinical trials to avoid biases and improve the outcomes.

The second finding of the review is that it provides, at a quick glance, which topic in the field has what type of publication and level of recommendation (Tables II and III). By sorting through the tables, it is feasible for clinicians and researchers alike to determine what kind of publications have been done for a given topic. From Tables II and III, one can determine which subject matter has the least or the most randomized trials, meta-, decision, cost-effective analyses, publications in weekly journals, and the strongest recommendations.

The third finding of the review is that gynecologic bulletins had much more level A recommendations than obstetric ones (Figure). Possible explanations for this disparity include that it is more feasible to do randomized trials among nonpregnant than gravid patients or that the caliber of the journals in which the studies are published are significantly different. But the types of studies are similar for obstetric and gynecologic bulletins, and the references cited for obstetric treatise are significantly more likely to appear in weekly journals or the 2 major journals than those in gynecologic bulletins (Table IV). Perhaps an overview of just quantifying the recommendations and types of reference is insufficient to explain the disparity. An in-depth analysis of each recommendation and the references leading to them may explain the difference between the 2 types of bulletins.

The fourth finding relates to the type of recommendations and its relationship to the quality of the journal in which the references were published. Level A recommendations in obstetric bulletins are significantly related to level I references $(\mathrm{r}=0.40$ and $P=.02)$, but such correlation does not exist for gynecologic bulletins. Moreover, there is a significant correlation between level $\mathrm{C}$ recommendations in obstetric bulletins and level III references, but such a relationship does not exist for gynecologic topics. Interestingly, there was no relationship with publications in the weekly general journals and the 3 types of recommendations. Whereas publications in other journals correlate significantly with level $\mathrm{C}$ recommendations in obstetric bulletins, they are related to level $\mathrm{B}$ recommendations in gynecologic bulletins. These relationships, although interesting, are 
hard to explain because the bulletins do not cite the specific reference that led to a particular recommendation.

There are limitations of the review that should be acknowledged. Like any other summary, a review article is hampered by the quality of publications it summarizes. But because the practice bulletins are developed arduously and with predefined objective criteria, the findings of this review do represent the current knowledge in obstetrics and gynecology. Even though we did find some minor errors in the classification of the references cited (available from the corresponding author), they were minimal and do not mitigate against the conclusion of the bulletins or this review. A potential problem is that since the publication of the bulletin, additional publications may have potentially strengthened or weakened the recommendations. We should acknowledge that ACOG has a vast array of other publications, and we examined only the practice bulletin. Lastly, we did not review or count the references cited in the meta-, decision, or costeffectiveness analyses to determine the total number of randomized clinical trials on which the ACOG recommendations are based.

The review does suggest additional things clinicians and ACOG can do to reach the stated goal of the practice bulletins: optimizing the outcomes and minimizing the cost and the likelihood of litigation claims. Linking the recommendations with references cited in the bulletin will allow a clearer understanding on how they are derived. A succinct summary of just the recommendations, available on a Web site or a pocket-sized book, could increase their awareness and possibly their compliance. Updating the recommendations annually or just confirming that there are no changes in them, would allow more confidence in complying with the suggestions. This could be done at ACOG or on the Obstetrics Gynecology Web site.

There is, it seems, a need to confirm or refute whether the publication of the guidelines has actually improved the outcome and protected against unnecessary litigation. ${ }^{65} \mathrm{We}$ need to compare the practice bulletins in our specialty with those of others to see how other fields practice and whether there are things we can do to improve the care of the women. Because the U.S. Preventive Services Task Force did suggest classifying recommendations as level $\mathrm{D}$ or $\mathrm{E},{ }^{1}$ the bulletin should consider using them or let the readers know why they are not being used. Lastly, when one bulletin is replaced, as was the case with vaginal birth after cesarean delivery, ${ }^{54,66}$ there should be a clear statement on the changes being made and the publications that prompted them.

In summary, among 438 recommendations made by ACOG, less than one third are based on good and consistent scientific evidence. Moreover, for every 10 references cited, not even 2 are a properly designed randomized clinical trial. The practice bulletins overview can be used by ACOG or the National Institute of Child Health and Human Development to focus and fund research in common obstetric and gynecologic conditions that lack adequately designed study. 


\section{References:}

1. American College of Obstetricians and Gynecologists, Reading the medical literature: applying evidence to practice. Washington DC: American College of Obstetricians and Gynecologists, 1998.

2. Gilbert W.M., Pitkin R.M., Society for maternal-fetal medicine meeting presentations: What gets published and why?. Am J Obstet Gynecol (2004) 191 : pp 32-35.

3. American College of Obstetricians and Gynecologists, ACOG educational and practice bulletins: list of titles, December 2004. Obstet Gynecol (2004) 104 : pp 1459-1460.

4. American College of Obstetricians and Gynecologists, Premature rupture of membranes. ACOG practice bulletin no 1. Washington, DC: American College of Obstetricians and Gynecologists, 1998.

5. American College of Obstetricians and Gynecologists, Medical management of tubal pregnancy. ACOG practice bulletin no 3. Washington, DC: American College of Obstetricians and Gynecologists, 1998.

6. American College of Obstetricians and Gynecologists, Prevention of Rh D alloimmunization. ACOG practice bulletin no 4. Washington, DC: American College of Obstetricians and Gynecologists, 1999.

7. American College of Obstetricians and Gynecologists, Thrombocytopenia in pregnancy. ACOG practice bulletin no 6. Washington, DC: American College of Obstetricians and Gynecologists, 1999.

8. American College of Obstetricians and Gynecologists, Prophylactic oophorectomy. ACOG practice bulletin no 7. Washington, DC: American College of Obstetricians and Gynecologists, 1999.

9. American College of Obstetricians and Gynecologists, Management of herpes in pregnancy. ACOG practice bulletin no 8. Washington, DC: American College of Obstetricians and Gynecologists, 1999.

10. American College of Obstetricians and Gynecologists, Antepartum fetal surveillance. ACOG practice bulletin no 9. Washington, DC: American College of Obstetricians and Gynecologists, 1999.

11. American College of Obstetricians and Gynecologists, Induction of labor. ACOG practice bulletin no 10. Washington, DC: American College of Obstetricians and Gynecologists, 1999.

12. American College of Obstetricians and Gynecologists, Medical management of endometriosis. ACOG practice bulletin no 11. Washington, DC: American College of Obstetricians and Gynecologists, 1999.

13. American College of Obstetricians and Gynecologists, Intrauterine growth restriction. ACOG practice bulletin no 12. Washington, DC: American College of Obstetricians and Gynecologists, 2000.

14. American College of Obstetricians and Gynecologists, External cephalic version. ACOG practice bulletin no 13. Washington, DC: American College of Obstetricians and Gynecologists, 2000. 
15. American College of Obstetricians and Gynecologists, Management of anovulatory bleeding. ACOG practice bulletin no 14. Washington, DC: American College of Obstetricians and Gynecologists, 2000.

16. American College of Obstetricians and Gynecologists, Premenstrual syndrome. ACOG practice bulletin no 15. Washington, DC: American College of Obstetricians and Gynecologists, 2000.

17. American College of Obstetricians and Gynecologists, Surgical alternative to hysterectomy in the management of leiomyomas. ACOG practice bulletin no 16. Washington, DC: American College of Obstetricians and Gynecologists, 2000.

18. American College of Obstetricians and Gynecologists, Operative vaginal delivery. ACOG practice bulletin no 17. Washington, DC: American College of Obstetricians and Gynecologists, 2000.

19. American College of Obstetricians and Gynecologists, The use of hormonal contraception in women with coexisting medical management. ACOG practice bulletin no 18. Washington, DC: American College of Obstetricians and Gynecologists, 2000.

20. American College of Obstetricians and Gynecologists, Thromboembolism in pregnancy. ACOG practice bulletin no 19. Washington, DC: American College of Obstetricians and Gynecologists, 2000.

21. American College of Obstetricians and Gynecologists, Perinatal viral and parasitic infections. ACOG practice bulletin no 20. Washington, DC: American College of Obstetricians and Gynecologists, 2000.

22. American College of Obstetricians and Gynecologists, Prevention of deep vein thrombosis and pulmonary embolism. ACOG practice bulletin no 21. Washington, DC: American College of Obstetricians and Gynecologists, 2000.

23. American College of Obstetricians and Gynecologists, Fetal macrosomia. ACOG practice bulletin no 22. Washington, DC: American College of Obstetricians and Gynecologists, 2000.

24. American College of Obstetricians and Gynecologists, Antibiotic prophylaxis for gynecologic procedures. ACOG practice bulletin no 23. Washington, DC: American College of Obstetricians and Gynecologists, 2001.

25. American College of Obstetricians and Gynecologists, Management of recurrent early pregnancy loss. ACOG practice bulletin no 24. Washington, DC: American College of Obstetricians and Gynecologists, 2001.

26. American College of Obstetricians and Gynecologists, Emergency oral contraception. ACOG practice bulletin no 25. Washington, DC: American College of Obstetricians and Gynecologists, 2001.

27. American College of Obstetricians and Gynecologists, Medical management of abortion. ACOG practice bulletin no 26. Washington, DC: American College of Obstetricians and Gynecologists, 2001.

28. American College of Obstetricians and Gynecologists, Prenatal diagnosis of fetal chromosomal abnormalities. ACOG practice bulletin no 27. Washington, DC: American College of Obstetricians and Gynecologists, 2001. 
29. American College of Obstetricians and Gynecologists, Use of botanicals for management of menopausal symptoms. ACOG practice bulletin no 28. Washington, DC: American College of Obstetricians and Gynecologists, 2001.

30. American College of Obstetricians and Gynecologists, Chronic hypertension. ACOG practice bulletin no 29. Washington, DC: American College of Obstetricians and Gynecologists, 2001.

31. American College of Obstetricians and Gynecologists, Gestational diabetes. ACOG practice bulletin no 30. Washington, DC: American College of Obstetricians and Gynecologists, 2001.

32. American College of Obstetricians and Gynecologists, Assessment of risk factors for preterm birth. ACOG practice bulletin no 31. Washington, DC: American College of Obstetricians and Gynecologists, 2001.

33. American College of Obstetricians and Gynecologists, Diagnosis and management of preeclampsia and eclampsia. ACOG practice bulletin no 33. Washington, DC: American College of Obstetricians and Gynecologists, 2002.

34. American College of Obstetricians and Gynecologists, Management of infertility caused by ovulatory dysfunction. ACOG practice bulletin no 34. Washington, DC: American College of Obstetricians and Gynecologists, 2002.

35. American College of Obstetricians and Gynecologists , Diagnosis and treatment of cervical carcinomas. ACOG practice bulletin no 35. Washington, DC: American College of Obstetricians and Gynecologists, 2001.

36. American College of Obstetricians and Gynecologists, Obstetric analgesia and anesthesia. ACOG practice bulletin no 36. Washington, DC: American College of Obstetricians and Gynecologists, 2002.

37. American College of Obstetricians and Gynecologists, Thyroid disease in pregnancy. ACOG practice bulletin no 37. Washington, DC: American College of Obstetricians and Gynecologists, 2002.

38. American College of Obstetricians and Gynecologists, Perinatal care at the threshold of viability. ACOG practice bulletin no 38. Washington, DC: American College of Obstetricians and Gynecologists, 2002.

39. American College of Obstetricians and Gynecologists, Selective estrogen receptor modulators. ACOG practice bulletin no 39. Washington, DC: American College of Obstetricians and Gynecologists, 2002.

40. American College of Obstetricians and Gynecologists, Shoulder dystocia. ACOG practice bulletin no 40. Washington, DC: American College of Obstetricians and Gynecologists, 2002.

41. American College of Obstetricians and Gynecologists, Polycystic ovary syndrome. ACOG practice bulletin no 41. Washington, DC: American College of Obstetricians and Gynecologists, 2002.

42. American College of Obstetricians and Gynecologists, Breast cancer screening. ACOG practice bulletin no 42. Washington, DC: American College of Obstetricians and Gynecologists, 2003. 
43. American College of Obstetricians and Gynecologists, Management of preterm labor. ACOG practice bulletin no 43. Washington, DC: American College of Obstetricians and Gynecologists, 2003.

44. American College of Obstetricians and Gynecologists, Neural tube defects. ACOG practice bulletin no 44. Washington, DC: American College of Obstetricians and Gynecologists, 2003.

45. American College of Obstetricians and Gynecologists, Cervical cytology screening. ACOG practice bulletin no 45. Washington, DC: American College of Obstetricians and Gynecologists, 2003.

46. American College of Obstetricians and Gynecologists, Benefits and risk of sterilization. ACOG practice bulletin no 46. Washington, DC: American College of Obstetricians and Gynecologists, 2003.

47. American College of Obstetricians and Gynecologists, Prophylactic antibiotics in labor and delivery. ACOG practice bulletin no 47. Washington, DC: American College of Obstetricians and Gynecologists, 2003.

48. American College of Obstetricians and Gynecologists, Cervical insufficiency. ACOG practice bulletin no 48. Washington, DC: American College of Obstetricians and Gynecologists, 2003.

49. American College of Obstetricians and Gynecologists, Dystocia and augmentation of labor. ACOG practice bulletin no 49. Washington, DC: American College of Obstetricians and Gynecologists, 2003.

50. American College of Obstetricians and Gynecologists, Osteoporosis. ACOG practice bulletin no 50. Washington, DC: American College of Obstetricians and Gynecologists, 2004.

51. American College of Obstetricians and Gynecologists, Chronic pelvic pain. ACOG practice bulletin no 51. Washington, DC: American College of Obstetricians and Gynecologists, 2004.

52. American College of Obstetricians and Gynecologists, Nausea and vomiting of pregnancy. ACOG practice bulletin no 52. Washington, DC: American College of Obstetricians and Gynecologists, 2004.

53. American College of Obstetricians and Gynecologists, Diagnosis and treatment of gestational trophoblastic disease. ACOG practice bulletin no 53. Washington, DC: ACOG, 2004.

54. American College of Obstetricians and Gynecologists, Vaginal birth after previous cesarean. ACOG practice bulletin no 54. Washington, DC: American College of Obstetricians and Gynecologists, 2004.

55. American College of Obstetricians and Gynecologists, Management of postterm pregnancy. ACOG practice bulletin no 55. Washington, DC: American College of Obstetricians and Gynecologists, 2004.

56. American College of Obstetricians and Gynecologists, Multiple gestation: complicated twin, triplet, and high-order multifetal pregnancy. ACOG practice bulletin no 56. Washington, DC: AC American College of Obstetricians and Gynecologists OG, 2004.

57. American College of Obstetricians and Gynecologists, Gynecologic herpes simplex virus infection. ACOG practice bulletin no 57. Washington, DC: American College of Obstetricians and Gynecologists, 2004. 
58. American College of Obstetricians and Gynecologists, Ultrasonography in pregnancy. ACOG practice bulletin no 58. Washington, DC: American College of Obstetricians and Gynecologists, 2004.

59. Scott J.R., Show me the evidence. Obstet Gynecol (2002) 100 : pp 403-404.

60. Sacks H., Chalmers T.C., Smith H. , Jr., Randomized versus historical controls for clinical trials. Am J Med (1982) 72 : pp 233-240.

61. Velanovich V., The quality of quality of life studies in general surgical journals. $J$ Am Coll Surg (2001) 193 : pp 288-296.

62. Grimes D.A., Schultz K.F., Methodology citations and the quality of randomized controlled trials in obstetrics and gynecology. Am J Obstet Gynecol (1996) 174 : pp 1312-1315.

63. Concato J., Shah N., Horwitz R.I., Randomized, controlled trials, observational studies, and the hierarchy of research designs. N Engl J Med (2000) $342:$ pp 1987-1992.

64. Parer J.T., Obstetric technologies: what determines clinical acceptance or rejections of results of randomized controlled trials?. Am J Obstet Gynecol (2003) 188 : pp 1622-1628.

65. McDonagh R.J., Hurwitz B., Lying in the bed we've made: reflection on some unintended consequences of clinical practice guidelines in the courts. J Obstet Gynaecol Can (2003) 25 : pp 39-43.

66. American College of Obstetricians and Gynecologists, Vaginal birth after previous cesarean delivery. ACOG practice bulletin no 5. Washington, DC: American College of Obstetricians and Gynecologists, 1999. 